\title{
Pengaruh Pemberian Air Buah Mengkudu (Morinda citrijolia L) terhadap Performans dan Berat Organ Dalam Ayam Broiler
}

The effect of mengkudu juice (morinda citrifolia 1.) on performances and internal organ of broiler

\author{
Yosi Fenita, Hidayat, M. Sukma
}

Jurusan Peternakan Fakultas Pertanian Universitas Bengkulu

Jalan Raya Kandang Limun, Bengkulu. Telp. (0736) 2170 pst.219.

\begin{abstract}
This research was conducted to evaluate the effect of mengkudu juice on performances (ration consumption, live weight and ration conversion) and internal organ weight percentage of gizzard, weight percentage of small intestine, length percentage of small intestine and weight percentage of liver). The research was conducted at Farm Laboratory of Animal Science Department, Faculty of Agriculture, University of Bengkulu. There were 64 broiler chickens divided into 4 treatments. The treatments were PO (as control without mengkudu juice mixed into 1 liter water), P1 ( $25 \mathrm{ml}$ mengkudu juice mixed into I liter water), P2 (50 ml mengkudu juice mixed into I liter water), P3 (75 in 1 mengkudu juice mixed into I liter water). The research design used was Completely Randomized Resign. There was significant effect $(\mathrm{P}<0.05)$ of mengkudu juice in water on ration consumption, live weight and ration conversion and no significant $(\mathrm{P}>0.05)$ to internal weight percentage of small, weight percentage of small intestine, length percentage of small intestine and weight percentage of liver. The results showed that mengkudu juice up to $75 \mathrm{ml}$ in water didn't give any best performances on broiler.
\end{abstract}

Key words: Morinda citrijolia, performance, broiler

\begin{abstract}
ABSTRAK
Penelitian ini dilakukan untuk mengevaluasi performans (konsumsi ransum, berat hidup dan konversi ransum) dan organ dalam (persentase berat gizzard, persentase berat usus halus, persentase panjang usus halus dan persentase berat hati) ayam broiler dengan pemberian air buah mengkudu. Penelitian ini dilaksanakan di Kandang Jurusan Peternakan, Universitas Bengkulu. Sejumlah 64 ekor ayam dibagi dalam 4 perlakuan. Perlakuan tersebut adalah P0 (sebagai kontrol tanpa pemberian air mengkudu ke dalam 1 liter air minum), P1 (25 ml air mengkudu dalam 1 liter air minum), P2 (50 ml air mengkudu dalam 1 liter air minum) dan P3 (75 ml air mengkudu dalam 1 liter air minum). Penelitian menggunakan Rancangan Acak Lengkap. Uji DMRT dilakukan untuk menguji perbedaan anter perlakuan. Terdapat perbedaan yang nyata $(\mathrm{P}<0,05)$ pemberian air buah mengkudu dalam air minum ayam broiler terhadap konsumsi ransum, berat hidup dan konversi ransum, persentase beret gizzard, persentase berat usus halus, persentase panjang usus halus dan persentase berat hati ayam broiler. Hasil penelitian menunjukkan bahwa air buah mengkudu hingga $75 \mathrm{ml}$ dalam air minum tidak memberikan performans yang baik pada ayam broiler.
\end{abstract}

Kata Kunci: Morinda citrijolia, performans, broiler

\section{PENDAHULUAN}

Pertambahan jumlah penduduk di
Indonesia menyebabkan peningkatan
kebutuhan akan protein hewani. Ayam
broiler merupakan ransum pilihan yang
tepat mengingat sifat-sifat unggulnya yaitu

tidak memerlukan tempat yang luas dalam pemeliharaannya, bergizi tinggi, pertumbuhan yang cepat dengan berat badan yang tinggi (Syahruddin, 1996).

Peningkatan produktivitas ternak dapat diusahakan dengan pemberian ransum suplemen. Medarti (1998) menyatakan, bahwa 
pemberian suplemen berupa air buah mentimun dalam air minum ayam broiler, ternyata meningkatkan pertambahan berat badan, Feed Cost Ratio, dan konversi ransum yang lebih baik dibandingkan dengan ayam broiler yang tidak diberi air buah mentimun.

Buah mengkudu (Morinda citrifolia L.) telah digunakan oleh penduduk Polinesia dan Kepulauan Caribian dalam mengobati berbagai penyakit dan untuk menyehatkan badan. Begitu juga di Indonesia, buah mengkudu sudah sejak lama dikenal dan digunakan dalam berbagai keperluan. Heinicke (2003) menemukan alkaloid di dalam buah mengkudu yang diberinya nama xeronine. Selain xeronine buah mengk-udu juga mengandung proxeronine dan enzitn proxeroninase yaitu enzim yang berfungsi mengaktifkan proxeronine untuk memproduksi. Xeronine ini sangat penting berbeda. Murdiati et al (2000) mengatakan, bahwa buah mengkudu memiliki kemampuan anthelmintik yang ditunjukkan oleh senyawa alkaloid dan untharaquinone dalam membunuh cacing Haemonchus contortus. Sibuea (2001) menyebutkan, bahwa komponen aktif lain di dalam buah mengkudu adalah scopoletin dan unthuruquinone.Scopoletin berperan mencegah penyumbatan pembuluh darah, antharaquinone mencegah diare karena berfungsi sebagai antimikrobia.

Novita (2003), menyatakan bahwa pemberian tepung buah mengkudu dengan level 3\% tidak berpengaruh terhadap konsumsi ransum, konversi ransum, pertambahan berat badan, dan persentase berat organ dalam ayam broiler.
Penelitian ini dilakukan untuk mengevaluasi pengaruh air buah mengkudu terhadap performans dan berat organ dalam broiler. Diduga pemberian air buah mengkudu hingga taraf $75 \mathrm{ml} / 1$ di dalam air minum memperbaiki performans dan berat organ dalam ayam broiler.

\section{MATERI DAN METODE}

Bahan-bahan yang digunakan selama penelitian ini adalah 64 ekor ayam broiler unsexing Strain Arbor Acres CP 707, air buah mengkudu, air minum, desinfektan merk Rodalon, vaksin ND merk Medivac ND Hitchner BI dan Medivac ND La-Sota.

Penelitian ini menggunakan kandang sistem litter yang berjumlah 16 petak, yang dilengkapi dengan tempat ransum dan tempat minum. Kandang dan peralatan didesinfektan sebelum digunakan. Kandang dan lokasi di sekitarnya diatur sedemikian rupa sehingga ventilasi dan pengaturan cahaya mendukung untuk pemeliharaan ayam broiler.

Ransum yang digunakan selama penelitian disusun sesuai dengan kebutuhan ayam broiler menurut NRC (1994). Pemeliharaan pada fase starter kandungan protein ransum adalah $23 \%$ dan Energi Metabolis $3200 \mathrm{Kkal} / \mathrm{kg}$, kemudian pada fase grower kandungan protein ransum adalah 20 \% dan Energi Metabolis $3200 \mathrm{Kkal} / \mathrm{kg}$. Ransum yang digunakan selama penelitian terlihat pada Tabel 1, 2 dan 3 di bawah ini.

Vaksinasi dilakukan pada umur 4 hari dengan vaksin ND Hitchner BI dan pada

Tabel 1. Komposisi zat-zat makanan bahan penyusun ransum (\%).

\begin{tabular}{|c|c|c|c|c|c|c|}
\hline Bahan Makanan & Protein & Lemak & Serat Kasar & $\mathrm{Ca}$ & $\mathrm{P}$ & $\mathrm{ME}(\mathrm{Kkal} / \mathrm{kg})$ \\
\hline Jagung Kuning & $9,27^{a}$ & $3,77^{a}$ & $2,82^{a}$ & $0,06^{a}$ & $0,29 a$ & $3370^{\mathrm{b}}$ \\
\hline Dedak Halus & $13,81^{\mathrm{a}}$ & $9,85^{\mathrm{a}}$ & $5,49^{a}$ & $0,10^{a}$ & $1,94^{\mathrm{a}}$ & $1630^{\mathrm{b}}$ \\
\hline Bungkil Kedele & $45,28^{a}$ & $1,33^{\mathrm{a}}$ & $3,11^{\mathrm{a}}$ & $0,39^{a}$ & $0,89^{a}$ & $2240^{b}$ \\
\hline Tepung Ikan & $58,75^{a}$ & $4,81^{a}$ & $1,09 a$ & $5,55^{a}$ & $3,38^{a}$ & $2830^{\mathrm{b}}$ \\
\hline Tepung Tulang & & & & $24^{\mathrm{b}}$ & $6^{\mathrm{b}}$ & \\
\hline Mineral Suplemen & & - & & $32,5^{c}$ & $10^{c}$ & \\
\hline Minyak Bimoli & & $99^{d}$ & & & & $9000^{d}$ \\
\hline
\end{tabular}

Keterangan: (a) Fenita (2002)

(b) Anggorodi (1985).

(c) Medion, (2002) Jakarta.

(d) Intiboga Sejahtera, (2002) Jakarta. 
Tabel 2. Formulasi ransum fase starter yaitu: 0-3 minggu (\%)

\begin{tabular}{lccccccc}
\hline Bahan Makanan & Jumlah & Protein & Lemak & SK & Ca & P & ME (Kkal/kg) \\
\hline Jagung kuning & 55,5 & 5,14 & 2,09 & 1,57 & 0,03 & 0,16 & $1.870,35$ \\
Dedak Halus & 5 & 0,69 & 0,49 & 0,27 & 0,01 & 0,10 & 81,50 \\
Bungkil Kedele & 20 & 9,06 & 0,27 & 0,62 & 0,08 & 0,18 & 448,00 \\
Tepung ikan & 14 & 8,23 & 0,67 & 0,15 & 0,78 & 0,47 & 396,20 \\
Tepung Tulang & 0,5 & - & - & - & 0,12 & 0,03 & - \\
Mineral Suplemen & 0,5 & - & - & - & 0,16 & 0,05 & - \\
Minvak Bimoli & 4,5 & - & 4,46 & - & - & - & 405,00 \\
\hline Total & 100 & 23,13 & 23,12 & 7,98 & 2,61 & 0,99 & $3.201,05$ \\
\hline
\end{tabular}

Tabel 3. Formulasi ransum fase grower yaitu: 4- 6 minggu (\%).

\begin{tabular}{|c|c|c|c|c|c|c|c|}
\hline Bahan Makanan & Jumlah & Protein & Lemak & SK & $\mathrm{Ca}$ & $\mathrm{P}$ & $\mathrm{ME}(\mathrm{Kkal} / \mathrm{kg})$ \\
\hline Jagung kuning & 60 & 5,56 & 2,26 & 1,69 & 0,04 & 0,17 & $2.022,00$ \\
\hline Dedak Halus & 7 & 0,97 & 0,69 & 0,38 & 0,01 & 0,14 & 114,10 \\
\hline Bungkil Kedele & 19,5 & 8,83 & 0,26 & 0,61 & 0,08 & 0,17 & 436,80 \\
\hline Tepung ikan & 8 & 4,70 & 0,38 & 0,09 & 0,44 & 0,27 & 226,40 \\
\hline Tepung Tulang & 0,5 & - & - & - & 0,12 & 0,03 & - \\
\hline Mineral Suplemen & 0,5 & - & - & - & 0,16 & 0,05 & - \\
\hline Minyak Bimoli & 4,46 & - & 4,42 & - & - & - & 401,40 \\
\hline Total & 100 & 20,06 & 8,01 & 2,77 & 0,85 & 0,83 & $3.200,70$ \\
\hline
\end{tabular}

umur 21 hari dengan vaksin ND La-Sota. Pada setiap fase ayam diberi ransum dan air minum ad libitum. Konsentrasi air buah mengkudu di dalam air minum sesuai dengan level perlakuan yaitu $0 \mathrm{ml}, 25 \mathrm{ml}, 50 \mathrm{ml}$ dan $75 \mathrm{ml}$. Buah mengkudu yang telah matang dibersihkan, lalu dihancurkan dengan blender, kemudian diperas dan disaring dengan menggunakan kain kasa untuk mengambil airnya. Air hasil penyaringan inilah yang diberikan terhadap ayam broiler.

Variabel yang diamati dalam penelitian ini adalah:

1. Konsumsi Ransum, diperoleh dari selisih antara ransum yang diberikan pada awal minggu dengan sisa ransum pada akhir minggu.

2. Pertambahan Berat Badan, diperoleh dengan cara mencari selisih berat badan diakhir minggu dengan berat badan pada minggu sebelumnya.

3. Konversi Ransum, didapat dari perbandingan antara ransum yang dikonsumsi dengan berat badan dalam waktu tertentu.

4. Persentase Berat Organ Dalam (gizzard, usus, hati), diperoleh setelah ayam dipuasakan selama 12 jam.
Penelitian ini menggunakan Rancangan Acak Lengkap (RAL) dengan 4 perlakuan dan 4 ulangan serta terdiri dari 4 ekor ayam tiap ulangan. Ayam yang dipotong untuk diambil data organ dalamnya adalah 2 ekor per unit kandang atau sejumlah 32 ekor.

Level perlakuan yang diberikan didasarkan pada konsumsi air mengkudu pada manusia yaitu $300 \mathrm{ml}$ per hari (Sibuea, 2001), dengan asumsi berat badan manusia $50 \mathrm{Kg}$ dan dikonversikan dengan rata-rata berat hidup ayam 1,5 Kg. Level perlakuan sebagai berikut:

P0 mengandung $0 \mathrm{ml}$ air buah mengkudu/liter air minum.

PI mengandung $25 \mathrm{ml}$ air buah mengkudu/liter air minum

P2 mengandung $50 \mathrm{ml}$ air buah mengkudu/liter air minum

P3 mengandung $75 \mathrm{ml}$ air buah mengkudu/liter air minum.

Analisa sidik ragam dilakukan untuk menguji pengaruh antar perlakuan. Perbedaan pengaruh antar perlakuan diuji lanjut dengan uji Duncant Multiple Range Test (DMRT) (Yitnosumarto, 1991) 


\section{HASIL DAN PEMBAHASAN.}

\section{Pengaruh Perlakuan terhadap Konsumsi Ransum} Pengaruh perlakuan dengan pemberian Air Buah Mengkudu terhadap konsumsi ransum kumuiatif ditunjukkan pada Tabel 4. Pemberian air Buah Mengkudu berpengaruh nyata $(\mathrm{P}<0,05)$ terhadap konsumsi ransum. Uji lanjut DMRT memberikan hasil bahwa penurunan yang nyata terhadap konsumsi ransum terjadi pada P2 dan P3 dibandingkan dengan kontrol dan P1. dalam ransum ayam broiler, ditemukan juga penurunan konsumsi ransum, tetapi tidak nyata $(\mathrm{P}>0,05)$.

\section{Pengaruh Perlakuan terhadap Pertambahan Berat Badan \\ Rataan Pertambahan Berat Badan} ayam broiler ditampilkan pada Tabel 5 . Pemberian air buah mengkudu sebesar $25 \mathrm{ml}$ per liter air minum (PI) menghasilkan pertambahan berat badan yang tidak berbeda nyata dengan P0 dan P2, tetapi berbeda dengan P3, sementara itu P2 tidak berbeda

Tabe1 4. Rataan konsumsi ransum kumulatif (g/ekor).

\begin{tabular}{ll}
\hline Perlakuan & Kumulatif \\
\hline P0 $(0 \mathrm{ml}$ air buah mengkudu $)$ & $2505,35^{\mathrm{a}}$ \\
P 1(25 ml air buah mengkudu $)$ & $2501,67^{\mathrm{a}}$ \\
P2 (50 ml air buah mengkudu $)$ & $2446,81^{\mathrm{b}}$ \\
P3 (75 ml air buah mengkudu $)$ & $2442,56^{\mathrm{b}}$ \\
\hline SD & 39,67 \\
P & $0.01^{*}$ \\
\hline
\end{tabular}

Keterangan: $\mathrm{a}$, $\mathrm{b}$ pada kolom yang sama menunjukkan perbedaan nyata $(\mathrm{P}<0,05)$

Respon penurunan konsumsi ransum pada level air mengkudu yang lebih tinggi ini (P2 dan P3) mungkin disebabkan oleh air mengkudu menyediakan zat-zat nutrisi yang dapat membantu memenuhi kebutuhan hidup ayam seperti karbohidrat, protein, asam amino dan vitamin. Seperti disebutkan oleh Heinicke (2004), bahwa kandungan air buah mengkudu mempunyai fungsi untuk melancarkan proses pencernaan zat-zat makanan. Jumlah ransum yang dibutuhkan oleh ayam bisa dipengaruhi oleh jenis ransum, kandungan ransum dan manfaat ransum (Murtidjo, 1987). Penelitian Novita (2003) yang memberikan buah mengkudu dalam bentuk tepung ke nyata dengan P0, P 1 dan P3. Lain halnya dengan $\mathrm{P} 3$ yang nyata $(\mathrm{P}<0,05)$ mengalami penurunan berat badan dibandingkan dengan P0, P1 dan P2. Penurunan yang nyata $(\mathrm{P}<0.05)$ pada pertambahan berat badan ini disebabkan karena terjadi penurunan yang sangat nyata $(\mathrm{P}<0,01)$ terhadap persentase kadar lemak daging sehingga mempengaruhi pertambahan berat badan. Penurunan yang sangat nyata $(\mathrm{P}<0,01)$ terhadap persentase kadar lemak daging sehingga mempengaruhi pertambahan berat badan. Penurunan yang sangat nyata $(\mathrm{P}<0,01)$ terhadap kadar lemak daging ditemukan oleh Novis (2004). Kenyataan ini memberikan suatu kejelasan bahwa semakin

Tabe1 5. Rataan pertambahan berat badan kumulatif (g/ekor).

\begin{tabular}{lc}
\hline Perlakuan & Kumulatif \\
\hline P0 (0 ml air buah mengkudu) & $1498,31^{\text {a }}$ \\
P 1(25 ml air buah mengkudu) & $1533,8 \mathrm{~T}^{\mathrm{a}}$ \\
P2 (50 ml air buah mengkudu) & $1441,87^{\mathrm{ab}}$ \\
P3 (75 ml air buah mengkudu) & $1377,06^{\mathrm{b}}$ \\
\hline SD & $0,03^{*}$ \\
P & 85,06 \\
\hline Keterangan: a, b pada kolom yang sama menunjukkan perberbedaan nyata $(\mathrm{P}<0,05)$
\end{tabular}


tinggi level air buah mengkudu di dalam air minum semakin menurun pertumbuhan ayam broiler. Somomon (2003), menemukan bahwa jus mengkudu dapat mengurangi penyakit jantung, menurunkan tekanan darah tinggi, obesitas dan menurunkan berat badan. Novita (2003), melaporkan bahwa semakin tinggi level tepung buah mengkudu juga menunjukkkan penurunan terhadap berat badan ayam broiler.

\section{Pengaruh Perlakuan terhadap Konversi Ransum}

Pengaruh perlakuan terhadap konversi ransum ayam broiler dapat dilihat pada Tabel 6. Pengaruh perlakuan berbagai level air buah mengkudu terhadap konversi

\section{Pengaruh Perlakuan terhadap Konsumsi Air} Minum

Pengaruh perlakuan terhadap kosumsi air minum ayam broiler ditunjukkan pada Tabel 7. Hasil penelitian menunjukkan penurunan yang tidak nyata $(\mathrm{P}>0,05)$ konsumsi air minum seiring dengan peningkatan level air mengkudu. Hal ini mungkin disebabkan karena air minum pada P1, P2 dan P3 memiliki kandungan nutrisi seperti vitamin dan mineral yang lebih baik dibandingkan dengan kontrol atau P0.

Menurut Wahju (1997), faktor-faktor yang dapat menurunkan atau menaikkan

Tabel 6. Rataan konversi ransum ayam broiler selama perlakuan (g/ekor).

\begin{tabular}{lc}
\hline Perlakuan & Kumulatif \\
\hline P0 $(0 \mathrm{ml}$ air buah mengkudu) & $1,67^{\mathrm{a}}$ \\
P1 (25 ml air buah mengkudu) & $1,63^{\mathrm{a}}$ \\
P2 (50 ml air buah mengkudu) & $1,70^{\mathrm{ab}}$ \\
P3 (75 ml air buah mengkudu) & $1,76^{\mathrm{b}}$ \\
\hline SD & 0,07 \\
\hline Keterangan: a, b pada kolom yang sama menunjukkan perberbedaan nyata $(P<0,05)$
\end{tabular}

ransum menunjukkan perbedaan yang nyata $(\mathrm{P}<0,05)$ pada P2 dan P3. Peningkatan ini disebabkan karena ransum yang dikonsumsi tidak menghasilkan berat badan yang meningkat. Menurut Rasyaf (1994), kualitas ransum, status alat-alat pencernaan ayam dan keseragaman berat hidup ayam mempunyai konsumsi air minum antara lain adalah tingkat garam natrium dan kalium dalam ransum, tingkat protein, tingkat serat kasar, enzimenzim, bau ransum, dan makanan tambahan pelengkap. Konsumsi air akan bertambah bila ada cekaman panas atau ransum mengandung kelebihan natrium, kalium,

Tabel 7. Rataan konsumsi air minum ayam broiler selama perlakuan (ml/ekor)

\begin{tabular}{ll}
\hline Perlakuan & Kumulatif \\
\hline P0 (0 ml air buah mengkudu) & 8320,31 \\
P1 (25 ml air buah mengkudu) & 8338,33 \\
P2 (50 ml air buah mengkudu) & 8122,50 \\
P3 (75 ml air buah mengkudu) & 7826,37 \\
\hline SD & 361,31 \\
P & $0,15^{\mathrm{ns}}$ \\
\hline Keterangan : Berbeda tidak nyata $(\mathrm{P}>0,05)$ &
\end{tabular}

dampak terhadap konversi ransum konversi ransum dipengaruhi oleh suhu, laju perjalanan ransum pada saluran pencernaan, bentuk fisik ransum, komposisi dan imbangan zatzat gizi ransum (Anggorodi, 1994). laktosa, atau beberapa zat yang harus diencerkan dan dikeluarkan.

Pengaruh Perlakuan terhadap Organ Dalam

Pengaruh air Buah Mengkudu terhadap organ dalam diperlihatkan pada Tabel 8 . Peningkatan berat gizzard berbeda tidak 
Tabe1 8. Rataan persentase berat gizzard, berat usus, panjang usus dan berat hati.

\begin{tabular}{lcccc}
\hline Perlakuan & Berat Gizzard $(\%)$ & Berat Usus $(\%)$ & Panjang Usus $(\mathrm{cm})$ & Berat Hati (\%) \\
\hline P0 $(0 \mathrm{ml})$ & 1,69 & 2,69 & $151,87^{\mathrm{b}}$ & 2,38 \\
P 1 $(25 \mathrm{ml})$ & 1,78 & 3,10 & $165,62^{\mathrm{a}}$ & 2,34 \\
P2 $(50 \mathrm{ml})$ & 1,93 & 2,87 & $165,56^{\mathrm{a}}$ & 2,42 \\
P3 $(75 \mathrm{ml})$ & 1,98 & 2,93 & $162,25^{\mathrm{a}}$ & 2,32 \\
\hline SD & 0,26 & 0,25 & 8,04 & 0,25 \\
P & $0,41^{\text {ns }}$ & $0,14^{\text {ns }}$ & $0,03^{*}$ & $0,95^{\text {ns }}$ \\
\hline
\end{tabular}

Keterangan $n s=$ tidak berbed a ny ata $(\mathrm{P}>0,05) ; \mathrm{a}, \mathrm{b}$ pada kolom yang sama menunjukkan berbeda nyata $(\mathrm{P}<0,05)$;

$$
\mathrm{SD}=\text { standar deviasi; } \mathrm{P}=\text { Probalitas; }
$$

nyata $(\mathrm{P}>0,05)$. Hal ini diduga karena pemberian level air buah mengkudu tidak mempengaruhi aktivitas kerja gizzard sehingga tidak terjadi kontraksi otot yang dapat mempengaruhi berat organ tersebut. Mirnawati dan Gita (2001), berpendapat bahwa salah satu faktor yang menyebabkan peningkatan berat gizzard adalah serat kasar ransum, makin tinggi serat kasar ransum dibutuhkan intensitas kerja yang lebih banyak bagi gizzard untuk mencernanya.

Perubahan yang tidak nyata $(P>0,05)$ pada berat usus ini mungkin sama dengan yang terjadi pada gizzard dan penyerapan yaitu tidak terjadi peningkatan kontraksi yang mempengaruhi beratnya. Rahim (1998), berpendapat bahwa ukuran usus dapat dipengaruhi oleh peningkatan kontraksi dan proses penyerapan sebagai akibat peningkatan konsumsi ransum.

Perlakuan menyebabkan peningkatan yang nyata $(\mathrm{P}<0,05)$ terhadap panjang usus masing-masing sebesar 9,05\%, 9,01\% dan 6,83\% berturut pada P1, P2, dan P3 dibandingkan dengan control. Peningkatan panjang usus tersebut berarti disebabkan level air mengkudu dan mungkin ditunjang juga oleh peningkatan kontraksi dan proses penyerapan. Selain itu mungkin juga disebabkan karena proses pembentukan xeronine terjadi di usus, sesuai dengan pendapat Heinicke (2004), bahwa enzim proxeronase yang ditemukan di dalam air mengkudu akan aktif di dalam usus dan merubah proxeronine menjadi xeronine murni. Peningkatan panjang usus juga berarti peningkatan fili-fili usus yaitu bagian dari organ usus yang berfungsi menyerap zat-zat makanan. Peningkatan penyerapan zat-zat nutrisi oleh villi-villi usus seharusnya meningkatkan pertambahan berat badan, tapi sebaliknya malah menurunkan pertambahan berat badan. Gejala ini dapat dijawab dengan penemuan Novis (2004), yaitu terjadi penurunan yang sangat nyata $(\mathrm{P}<0,01)$ terhadap persentase kadar lemak daging sehingga mempengaruhi pertambahan berat badan. Solomon (2004), menyatakan sari buah mengkudu berkhasiat mengobati penyakit darah tinggi, kolesterol, stroke, kanker, asam urat, dengan tingkat keberhasilan $78 \%$, Amin (2003), menemukan bahwa ransum dengan kadar tepung buah mengkudu hingga 3\% tidak memberikan pengaruh terhadap panjang usus, berat usus, gizzard dan hati.

Perlakuan tidak menyebabkan perubahan yang nyata $(\mathrm{P}>0,05)$ terhadap persentase berat hati. Hati menyimpan sejumlah proxeronin yang meruransum prekursor (zat pembentuk) xeronin yang sangat dibutuhkan oleh tubuh (Bahalwan dan Driva, 2002). Pemberian air buah mengkudu berarti menyediakan pasokan proxeronin yang lebih banyak sehingga fungsi dan kerja organ hati lebih efisien. Sejalan dengan pendapat Heinicke (2004), bahwa xeronine yang terbentuk dari proxeronin digunakan oleh tubuh untuk membantu memelihara sel-sel secara tepat dan efisien.

\section{SIMPULAN}

\section{Kesimpulan}

Berdasarkan hasil penelitian dapat disimpulkan bahwa pemberian Air Buah Mengkudu menyebabkan konsumsi ransum dan pertambahan berat badan yang menurun serta meningkatkan konversi ransum pada level 50 dan $75 \mathrm{ml} / 1$ air minum, dengan kata lain 
pada kedua level tersebut air buah mengkudu tidak memperbaiki performans ayam broiler.

\section{Saran}

Penulis menyarankan untuk melakukan penelitian lebih lanjut pemberian air buah mengkudu dengan level maksimal $25 \mathrm{ml} / \mathrm{l}$ air minum.

\section{DAFTAR PUSTAKA}

AAK, 1986. Beternak Ayam Pedaging. Kanisius. Yogyakarta

AAK, 1981. Pemeliharaan Ayam Ras. Kanisius. Yogyakarta

Amin, A., 2003. Pengaruh pemberian tepung buah mengkudu (Morinda citrifolia L.) dalam ransum terhadap berat karkas, berat organ dalam dan kadar kolesterol darah ayam broiler. Prog Studi Produksi Ternak. Fakultas Pertanian. Universitas Bengkulu. Bengkulu.

Amrullah, I. K., 2003. Nutrisi Ayam Broiler. Lembaga Satu Gunung Budi. Seri Beternak Sendiri. Edisi Pertama. Bogor.

Anggorodi, R., 1994. Ilmu Makanan Ternak Umum. Gedia Pustaka Utama. Jakarta.

Bahalwan, R. R. dan D. Sjabana, 2002. Pesona Tradisional dan Ilmiah Mengkudu. Seri Referensi Herbal. Salemba Medika. Edisi pertama. Jakarta.

Bangun, A. P dan B. Sarwono, 2002. Khasiat dan Manfaat Mengkudu. Cet. 1. Agro Media Pustaka. Jakarta.

Blakely, J. dan D. H. Bade, 1985. Ilmu Peternakan. Gajah Mada University Press, edisi keempat, Jogjakarta.

Church, D. C. and W. G. Pond, 1988. Basic Animal Nutrition and Feeding. Third edition. John Wiley and Sons,.Inc. Canada.

Fenita. Y. 2002. Suplementasi lisin dan metionin serta minyak lemuru ke dalam ransum berbasis hidrolisat bulu ayam terhadap perlemakkan dan pertumbuhan ayam ras pedaging. Disertasi. Program Pascasarjana IPB, Bogor.

Frandsond, R. D., 1993. Anatomi dan Fisiologi Ternak. Gajah Mada University Press,
Jogj akarta.

Heinicke, R. M., 2003. The pharmacologically active ingrediend of noni, httu://wwwiwr.com/noniluice/xeronine.htm. 10 Jun 2003.

Heinicke, R. M., 2004. How xeronine is made in the body, http://www iwr.comlnoniiuice/xeronine.htm. 8 Peb 2004.

Heinicke, R. M., 2004. What is xeronine? http://wwwxeronineProxeronineenzymes ofNoniJuicel.htm. 3 Mar 2004.

Medarti, Y, 1998. Performans pertumbuhan dan fisiologi ayam broiler jantan yang diberi air mentimun (Cucumis sativus). Prog Studi Produksi Ternak. Fakultas Pertanian. Universitas Bengkulu. Bengkulu.

Murtidjo, B. A., 1987. Pedoman Beternak Ayam Broiler. Kanisius Edisi pertama, Jogjakarta.

Moreng, R. E. and J. S. Avens, 1985. Poultry Science and Production. Reston Publishing company. Virginia.

National Research Council, 1994. Nurient Requirements of Poultry. National Academy of Sciences. Washington, D. C.

Novis. A. 2004. Pengaruh pemeberian air mengkudu terhadap kualitas karkas ayam broiler. Skripsi. Jurusan Peternakan. Fakultas Pertanian Universitas Bengkulu.

Rahim, F., 1998. Pengaruh penambahan asam folat dalam ransum terhadap konsumsi makanan, tebal usus halus dan beberapa nilai fisiologis darah ayam broiler. Jurnal Peternakan dan Lingkungan, Fakultas Pertanian, Universitas Andalas, Padang.

Rasyaf, M., 1994. Beternak Ayam Kampung. Cet 14. Penebar Swadaya. Jakarta

Rasyaf, M., 1995. Beternak Ayam Pedaging. Penebar Swadaya. Jakarta

Rasyaf, M., 2001. Beternak Ayam Pedaging. Cet 20. Penebar Swadya. Jakarta

Susanti, N., Pengaruh pemberian tepung buah mengkudu (Morinda citrifolia L.) terhadap performans ayam broiler. Prog Studi Produksi Ternak. Fakultas Pertanian. Universitas Bengkulu. Bengkulu.

Syamsuhadi, 1997. Penggunaan duckweed 
(famili Lemnaceae) sebagai ransum serat sumber protein dalam ransum ayam pedaging. Disertasi Pascasarjana IPB. Bogor.

Sarwono, B. dan A. P. Bangun, 2002. Khasiat dan Manfaat Mengkudu. Agro Media Pustaka. Edisi pertama, Jakarta.

Scoth, M.L., M. C. Nesheim and R. J. Young, 1982. Nutrion of the Chicken, M.L. Scott and Associates, Ithaca, New York.

Sibuea, P., 2001. Mengkudu, buah beraroma busuk dengan sejuta manfaat. Nova. N0.705/XIV : 29-30.

Solomon, N., 2004. Kandungan mengkudu. Artikel tentang mengkudu. http://www com / -timo/science/scientifik. Html. 31 Maret.

Solomon, N., 2004. Nature Amazing Healer, http://www healthv-sunshine.com/nonibenefits.htm. 8 Peb 2004.

Solomon, N., 2004. Noni juice the tropical fruit with 101 medicinal uses, htt -//www healthy-sunshine.com/noni-benefit. htm. 8 Peb 2004.

Syahruddin, E., 1996. Penambahan minyak kedelai dalam ransum untuk menurunkan kadar lemak dan kolesterol karkas broiler. Jurnal Peternakan dan Lingkungan, Fakultas Pertanian, Universitas Andalas, Padang.

Wahju, J., 1997. Ilmu Nutrisi Unggas. Edisi 4. Gajah Mada University Press. Yogjakarta.

Yitnosumarto, S., 1991. Percobaan, Analisis dan Interpretasinya. Gedia Pustaka Utama. Jakarta. 